\title{
Sources of Soil Pollution by Heavy Metals and Their Accumulation in Vegetables: a Review
}

\author{
Aneta Zwolak (D) - Magdalena Sarzyńska • \\ Ewa Szpyrka $\cdot$ Kinga Stawarczyk
}

Received: 15 April 2019 / Accepted: 27 June 2019 / Published online: 6 July 2019

(C) The Author(s) 2019

\begin{abstract}
The presence of heavy metals in food is a threat to human health. Exposure to heavy metals as a result of consumption of contaminated vegetables, as well as their toxicity, is a serious problem.

Different branches of industry and the road traffic have a significant impact on environmental pollution with heavy metals. Municipal and industrial sewage also is an important source of those substances. Furthermore, the mineral content of vegetables depends on factors such as the natural content of trace elements in the environment, their levels in mineral fertilizers, and fertilizer doses. In the soil, a natural source of these metals is bedrock. In soils used for agricultural purposes, some quantities of metals are introduced together with fertilizers, both organic and mineral. Additionally, another sources of the metals are plant protection products.

Heavy metal dynamics in the soil and their uptake by plants are influenced by soil properties, which play a key role in the bioavailability of these metals. Metal mobility and assimilation are also influenced by the addition of organic and inorganic matter. A significant body of evidence also suggest that the age of the soil plays an important role in modulation of metal bioavailability to plants.
\end{abstract}

\footnotetext{
A. Zwolak $(\bowtie) \cdot$ M. Sarzyńska $\cdot$ E. Szpyrka

University of Rzeszow, Faculty of Biotechnology, 1 Pigoń St., 35-310 Rzeszów, Poland

e-mail: azwolak@ur.edu.pl

K. Stawarczyk

Veterinary Inspectorate Mielec, Skłodowskiej 8, 39-300 Mielec, Poland
}

Apart from being influenced by the soil-related factors, absorption of metals differs in different types of plants. A significant variation in metal concentrations was also found depending on their location in plant tissues, on plant species, or even on varieties of the same species.

Keywords Heavy metals · Soil pollution · Vegetables · Accumulation · Contamination

\section{Introduction}

The problem of heavy metal contamination in the environment is widespread. Taken up by plants, heavy metals may enter the food chain, and therefore, humans can also be exposed to them (Intawongse and Dean 2006). A recently published $\mathrm{WHO} / \mathrm{FAO}$ report recommends consumption of minimum of $400 \mathrm{~g}$ of fruit and vegetables per day (excluding potatoes and other starchy tubers) for prevention of chronic diseases such as heart diseases, cancer, diabetes, and obesity, as well as for prevention and alleviation of several micronutrient deficiencies, especially in less developed countries (WHO 2004).

Heavy metals are widely distributed in the environment and are considered significant chemical food contaminants. The group of heavy metals includes both elements essential for normal metabolic processes, called micronutrients ( $\mathrm{Fe}, \mathrm{Mn}, \mathrm{Cu}, \mathrm{Zn}, \mathrm{Mo}$ ), which in excessive quantities are more harmful to plants than to animal bodies, as well as elements such as $\mathrm{As}, \mathrm{Hg}, \mathrm{Pb}$, 
or $\mathrm{Cd}$, which already at low concentrations are very harmful to humans and animals, while affecting plant growth and development to a lesser extent.

According to their toxicity to living organisms, the heavy metals can be arranged in the following order: $\mathrm{Hg}>\mathrm{Cu}>\mathrm{Zn}>\mathrm{Ni}>\mathrm{Pb}>\mathrm{Cd}>\mathrm{Cr}>\mathrm{Sn}>\mathrm{Fe}>\mathrm{Mn}>$ $\mathrm{Al}$ (Wang et al. 2003; Pueyo et al. 2004; Filipiak-Szok et al. 2015).

Heavy metals present in food, even in trace amounts, pose a threat to human health. In different parts of the world, different acceptable levels for heavy metal content in foodstuffs were adopted:

- EU Commission Regulation No 1881/2006 of 19 December 2006 and amending Regulation No 420/ 2011 of 29 April 2011. Setting maximum levels for certain contaminants in foodstuffs (Text with EEA relevance);

- Codex Alimentarius Commission (CODEX)-CODEX STAN 193-1995 (Amendment 2010). Established maximum of five heavy metals: arsenic, cadmium, lead, mercury (including methylmercury), tin;

- Mainland-GB 2762: Maximum levels of contaminants in food. Established maximum levels of six heavy metals: arsenic, cadmium, chromium, lead, mercury (including methylmercury), tin;

- US Food and Drug Administration (FDA). The US Food and Drug Administration (FDA) has not established regulatory limits for heavy metals in finished food products other than bottled water. However, the Agency has provided guidance on some heavy metal levels in certain foods (such as candy and juice). For juice, FDA states in its "Guidance for Industry: Juice HACCP Hazards and Controls" that lead levels in juice above $50 \mathrm{ppb}$ may constitute a health hazard. With respect to candy, FDA recommends a maximum lead level of $100 \mathrm{ppb}$ in candy likely to be consumed by small children;

- China National Standards (GB 2762-2012).

Due to differences in national legislations and the related risk of distortion of competition, it is necessary to introduce measures in respect of certain pollutants, heavy metals in particular, to ensure homogeneity of the market, with a due regard for the principle of proportionality.

The maximum levels of heavy metals in foodstuffs of plant origin should be set at the strictest possible level that is reasonably achievable by good practices of agricultural industry, and taking into account the risks associated with food consumption. For contaminants that are considered genotoxic carcinogens, or in cases where the current exposure of the population or the most vulnerable population groups is close to or exceeds the tolerated uptake, the highest permitted levels should be set at the lowest reasonably achievable level.

The exposure to cadmium, lead, and methylmercury compounds is especially dangerous during prenatal development and infancy, as it causes irreversible changes in the central nervous system. Lead also causes cardiovascular diseases, disrupts heme biosynthesis and vitamin D metabolism, causes kidney and liver dysfunctions and disorders of the immune and the reproductive systems, and disrupts iron, zinc, and copper metabolism. Cadmium is carcinogenic, neurotoxic, and nefrotoxic, and causes skeletal disorders, liver damage, cardiovascular diseases, dysfunctions of the sexual glands, and disrupts a mineral balance in the body. Mercury, and especially the methylmercury compounds, accumulates mainly in the brain tissue, causing damage to the central nervous system, especially the developing fetal brain. In adults, it causes hearing, speech, and visual disorders, cardiovascular diseases, and limb muscle paralysis. Arsenic has carcinogenic, neurotoxic (hearing disorders), and genotoxic effects, and causes cardiovascular diseases, peripheral vascular disorders, anemia, and dysfunctions of the reproductive system (WojciechowskaMazurek et al. 2008; Shaheen et al. 2016).

Due to their properties such as toxicity, persistence, and non-biodegradation, contamination with metals has become a serious and widespread environmental threat, particularly in urban areas (Yang-Guang et al. 2016).

The problem of heavy metals stems out not only from their toxic properties but also from their ability to accumulate in the body, as it is a case with all elements listed above. At low levels of exposure to these elements, clinical signs do not manifest immediately and their effects can be observed only at the physiological or biochemical level (Wojciechowska-Mazurek et al. 2008).

\section{Sources of Contaminations with Heavy Metals}

The rapid global industrial development has resulted in a significantly increased risk of environmental contamination with heavy metals. Fast industrialization and disorganized urbanization, together with long-term use of large 
amounts of fertilizers and pesticides, result in accumulation of toxic substances in soil, water, and air (Kishan et al. 2014; Kumar et al. 2015; Rodriguesa et al. 2017).

The main sources of emissions caused by human activities include:

- Emissions from mobile sources related to vehicle transport and fuels, called linear emission

- Processes of energy combustion of fuels, and industrial technological processes, discharging substances into the air through an emitter (stack) in an organized manner, called point emission sources;

- Emissions related to house heating in the municipal and household sector, called surface emission (WIOŚ Szczecin 2015).

Exposure to heavy metals resulting from consumption of contaminated vegetables and their toxicity is a serious problem. An increased content of certain elements is found particularly in vegetables grown in the vicinity of industrial plants and busy roads, as well as in crops exposed to municipal and agricultural wastewater. This may lead to a disrupted balance of these elements, and, in turn, significantly affect their bioavailability and interaction with other food ingredients, as well as other metals (Wong et al. 2006; Śmiechowska and Florek 2011).

Different branches of industry, as well as road traffic, have a significant impact on environmental pollution with heavy metals, such as the following: chrome from metallurgical, paint, and tanning industries; nickel mainly from the steel industry, and burning of coal and liquid fuel; cadmium from metal (mostly zinc) smelters, while along roads another source of contamination with this element may be grease used in motor vehicles; and lead from paint, metallurgical, and glass industries. The main sources of lead contamination in soils, plants, and air are the exhaust gases of motor vehicles. For many years, lead had been added to petrol as lead tetraethyl, which was released during mechanical engine operation (Lityński and Jurkiewicz 1982; Nieć et al. 2013; Zhou et al. 2016). In Poland, universal petrol (containing lead tetraethyl) was withdrawn from the market in January 2005 and was replaced with unleaded petrol.

Numerous studies conducted in recent years found a large share of street dust in contaminants of urban soils near traffic routes (Czarnowska and Bednarz 2000; Sternbeck et al. 2002; Zereini et al. 2007, 2012; Wiseman et al. 2013, 2015). Heavy metals come from motor vehicle exhaust emissions; their release is also associated with vehicle wear parts, such as tires, brakes, and catalysts. The re-suspension of metal-enriched road dust caused by vehicle traffic may also be the main source of road pollution, especially along roads with more intense traffic and higher proportion of heavy vehicles (Czarnowska and Bednarz 2000; Sternbeck et al. 2002; Lough et al. 2005; Wiseman et al. 2013, 2015).

A risk of heavy metal presence in vegetables cultivated near old industrial areas is significant (Sun and Chen 2018; Murray et al. 2011; Sung and Park 2018), and this kind of contamination is rather problematic.

Municipal and industrial sewage is also an important source of heavy metals. Wastewater irrigation is a common practice in the world, and in some metropolitan areas, wastewater is treated biologically and used for irrigation in agriculture. In recent years, many articles about soils irrigated with wastewater contaminated with heavy metals were published. On the basis of their studies, Mahmood and Malik (2014) showed that wastewater irrigation has changed physical and chemical properties of the soil and led to heavy metal uptake by plants, mostly vegetables. Earlier reports from Pakistan confirmed that vegetables grown in effluents accumulate higher concentrations of heavy metals than vegetables grown in groundwater (Akbar et al. 2009; Jan et al. 2010; Khan et al. 2013). Similar conclusions were also reached by Khan et al. (2008) on the basis of their studies conducted in China.

\section{Soil Factors Affecting Metal Accumulation}

The mineral content of vegetables also depends on factors such as the natural content of trace elements in the environment, their level in mineral fertilizers, and fertilizer doses. In the soil, a natural source of these metals is bedrock. In soils used for agricultural purposes, some quantities of metals are introduced together with fertilizers, both organic and mineral (mainly calcium and phosphates). Additionally, another sources of metals are plant protection products (Kabata-Pendias and Pendias 1999; Antisari et al. 2015; Ye et al. 2015).

Heavy metal dynamics in the soil and their uptake by plants depend on soil properties, which play a key role in the bioavailability of these metals. The level of these compounds' accumulation in plants depends on, amongst others, soil type, $\mathrm{pH}$, humidity, and micronutrients content, as well as on the time of crop harvesting (Kabata-Pendias and Pendias 1999; Järup 
2003; Leitzmann 2003; Właśniewski and Hajduk 2012; Yang-Guang et al. 2016; Hu et al. 2017).

On the basis of their research, Właśniewski and Hajduk (2012) associated the high cadmium content mainly with the granulometric composition of the soils, and then with their location along busy traffic routes. Furthermore, they showed that the cadmium content in tested vegetables was, to a very small extent, associated with the properties of the soil top layer, including a soil content of total and soluble cadmium.

Kabata-Pendias and Pendias (1999) claimed that acidic soil $\mathrm{pH}$ is considered to be the most important factor influencing the increased absorption of heavy metals by vegetables. This was confirmed by research conducted by Bielecka et al. (2009), which showed that, in alkaline soils ( $\mathrm{pH}$ within the range of 7.1-8.1), a risk of heavy metal leaching and their bioavailability to plants are lower, and the presence of organic matter can inhibit metals uptake from the soil solution. By changing these soil properties that determine metal solubility in the soil, heavy metals can be immobilized in its solid phase. Metal mobility and bioavailability may be influenced by addition of organic and inorganic matter. A basic treatment restricting metal mobility is soil de-acidification by liming. Application of phosphate also affects soil heavy metal mobility and assimilation by plants (Finžgar et al. 2006; Wuana and Okieimen 2011; Zhang et al. 2010; Paltseva et al. 2018).

Studies have shown that the use of phosphates stabilizes $\mathrm{Pb}$ by reducing its availability in the soil. However, this effect depends on the soil type and is not sufficiently described, similarly as plants' ability to take up lead. The researchers speculate that phosphates can mobilize As. The addition of phosphate increases soil permeability, thus contributing to arsenic migration deeper into the soil profile and entering groundwaters. This involves increasing its availability and uptake by plants (Scheckel et al. 2013; McBride et al. 2014; McBride et al. 2015; Lim and McBride 2015).

Adding materials rich in organic components, such as compost, sawdust, tree bark, or granulated or powdered lignite, is frequently recommended to reduce mobility and bioavailability of metals. Some researchers suggest that regular addition of organic matter in large quantities

Table 1 Heavy metal concentration in edible parts of vegetables from China, depending on species (mg/kg). Data show mean $\pm \mathrm{standard}$ error of three replicates Hang et al. (2016)

\begin{tabular}{|c|c|c|c|c|c|c|}
\hline Vegetable type & Vegetable species & $\mathrm{Pb}(\mathrm{mg} / \mathrm{kg})$ & As $(\mathrm{mg} / \mathrm{kg})$ & $\mathrm{Cd}(\mathrm{mg} / \mathrm{kg})$ & $\mathrm{Zn}(\mathrm{mg} / \mathrm{kg})$ & $\mathrm{Cu}(\mathrm{mg} / \mathrm{kg})$ \\
\hline \multirow[t]{4}{*}{ Root } & White radish & $0.270 \pm 0.057$ & $0.099 \pm 0.012$ & $0.011 \pm 0.003$ & $4.690 \pm 1.367$ & $0.167 \pm 0.073$ \\
\hline & Carrot & $0.233 \pm 0.001$ & $0.188 \pm 0.030$ & $0.023 \pm 0.005$ & $1.591 \pm 0.092$ & $0.227 \pm 0.011$ \\
\hline & Sweet potato & $0.613 \pm 0.162$ & $0.448 \pm 0.013$ & $0.135 \pm 0.007$ & $4.674 \pm 0.790$ & $0.015 \pm 0.005$ \\
\hline & National standard (China) ${ }^{\mathrm{a}}$ & 0.1 & 0.5 & 0.1 & - & - \\
\hline \multirow[t]{3}{*}{ Stalk } & White caitai & $0.785 \pm 0.239$ & $0.225 \pm 0.043$ & $0.239 \pm 0.090$ & $24.23 \pm 5.541$ & $0.456 \pm 0.033$ \\
\hline & Red caitai & $0.939 \pm 0.327$ & $0.396 \pm 0.076$ & $0.176 \pm 0.038$ & $20.95 \pm 2.993$ & $0.478 \pm 0.089$ \\
\hline & National standard (China) ${ }^{\mathrm{a}}$ & 0.3 & 0.5 & 0.1 & - & - \\
\hline \multirow[t]{3}{*}{ Solanaceous } & Eggplant & $0.429 \pm 0.001$ & $0.072 \pm 0.004$ & $0.289 \pm 0.027$ & $2.786 \pm 0.588$ & $0.937 \pm 0.199$ \\
\hline & Tomato & $0.078 \pm 0.023$ & $0.014 \pm 0.003$ & $0.028 \pm 0.005$ & $1.419 \pm 0.185$ & $0.468 \pm 0.036$ \\
\hline & National standard (China) ${ }^{a}$ & 0.1 & 0.5 & 0.05 & - & - \\
\hline \multirow[t]{3}{*}{ Melon } & Pumpkin & $0.121 \pm 0.031$ & $0.073 \pm 0.015$ & $0.005 \pm 0.001$ & $2.883 \pm 0.749$ & $0.647 \pm 0.104$ \\
\hline & Cucumber & $0.004 \pm 0.001$ & $0.039 \pm 0.014$ & $0.004 \pm 0.001$ & $1.206 \pm 0.107$ & $0.284 \pm 0.047$ \\
\hline & National standard (China) ${ }^{\mathrm{a}}$ & 0.1 & 0.5 & 0.05 & - & - \\
\hline \multirow[t]{4}{*}{ Leafy } & Lettuce & $1.162 \pm 0.540$ & $0.660 \pm 0.086$ & $0.460 \pm 0.207$ & $11.79 \pm 1.688$ & $0.775 \pm 0.170$ \\
\hline & Spinach & $0.971 \pm 0.194$ & $0.310 \pm 0.064$ & $0.513 \pm 0.055$ & $20.81 \pm 4.543$ & $0.966 \pm 0.288$ \\
\hline & Cabbage & $0.671 \pm 0.277$ & $0.211 \pm 0.014$ & $0.036 \pm 0.022$ & $9.926 \pm 2.226$ & $0.314 \pm 0.043$ \\
\hline & National standard (China) ${ }^{\mathrm{a}}$ & 0.3 & 0.5 & 0.2 & - & - \\
\hline \multirow[t]{3}{*}{ Legume } & Kidney bean & $0.033 \pm 0.036$ & $0.050 \pm 0.010$ & $0.010 \pm 0.017$ & $5.669 \pm 0.236$ & $1.310 \pm 0.085$ \\
\hline & Asparagus bean & $0.070 \pm 0.014$ & $0.047 \pm 0.014$ & $0.013 \pm 0.011$ & $6.682 \pm 1.550$ & $1.999 \pm 1.247$ \\
\hline & National standard (China) ${ }^{\mathrm{a}}$ & 0.2 & 0.5 & 0.1 & - & - \\
\hline
\end{tabular}

${ }^{\mathrm{a}}$ The tolerance limit for contaminants specified in foodstuffs in the China National Standards (GB 2762-2012) 
may inhibit metal uptake from the soil solution, and thus would be advantageous (Brown et al. 2012; Attanayake et al. 2014, 2015). Defoe et al. (2014) and Karczewska et al. (2010) confirmed that organic matter stabilizes trace elements in the soil, while Murray et al. (2011) showed that the addition of compost may lead to increased accumulation of metals in cultivated plants. McBride et al. (2015), on the other hand, found that $\mathrm{Pb}$ and $\mathrm{As}$ levels in vegetables were strongly correlated with a total content of these metals in the soil, and not with organic matter content in the soil or a level of compost addition.

Bai et al. (2011) and Wiseman et al. (2015) provided evidence that the soil age also plays an important role in modulation of metal bioavailability in plants. A higher content of heavy metals was found in old flat wetlands due to long-term discharges of municipal and industrial wastewater. A multivariate analysis shows that bedrock is a source of $\mathrm{Fe}$ and $\mathrm{Mn}$, while $\mathrm{Cu}, \mathrm{Zn}, \mathrm{Cd}, \mathrm{Cr}, \mathrm{Ni}$, and $\mathrm{Pb}$ are of anthropogenic origin. When compared with wet ditches and reclaimed wetlands, levels of some heavy metals, such as $\mathrm{Pb}, \mathrm{Cd}$, and $\mathrm{Zn}$, are much higher in wetlands in a young region because these wetlands are richer in mangrove soils. Higher toxic levels of heavy metals in flat wetlands and recovered wetlands in an old region are observed because of their long history of reclamation, when compared with lowland wetlands (Bai et al. 2011).

Apart from being influenced by the soil-related factors, absorption of metals differs in different types of plants. A significant variation in metal concentrations was also found depending on their location in plant tissues, on plant species and even on varieties of the same species (Szatanik-Kloc 2004; Karami et al. 2011; Zhou et al. 2016).

On a basis of her research, Szatanik-Kloc (2004) reported that she did not observe any relevant correlation between the concentration of $\mathrm{Cr}, \mathrm{Ni}$, and $\mathrm{Cd}$ in the soil and in the plant (only $\mathrm{Pb}$ content in leaves showed a large dependence on its contents in the topsoil).

Table 2 Concentrations of heavy metals in edible parts of vegetables from UK, depending on species and cultivar ( $\mathrm{mg} / \mathrm{kg}$ ) Alexander et al. (2006)

\begin{tabular}{|c|c|c|c|c|c|}
\hline Vegetable species & Vegetable cultivar & $\begin{array}{l}\mathrm{Cd} \\
(\mathrm{mg} / \mathrm{kg})\end{array}$ & $\begin{array}{l}\mathrm{Pb} \\
(\mathrm{mg} / \mathrm{kg})\end{array}$ & $\begin{array}{l}\mathrm{Zn} \\
(\mathrm{mg} / \mathrm{kg})\end{array}$ & $\begin{array}{l}\mathrm{Cu} \\
(\mathrm{mg} / \mathrm{kg})\end{array}$ \\
\hline \multirow[t]{4}{*}{ Carrot } & Amsterdam & 2.521 & 6.310 & 52.590 & 5.770 \\
\hline & Nantes & 1.812 & 5.010 & 19.020 & 4.43 \\
\hline & Wlewek & 2.298 & 7.230 & 33.380 & 4.43 \\
\hline & European standards ${ }^{\mathrm{b}}$ & 0.1 & 0.1 & - & - \\
\hline \multirow[t]{4}{*}{ Spinach } & Bloomsdale & 4.24 & 1.74 & 334.9 & 9.01 \\
\hline & G. Thick Leaved & 5.13 & 1.68 & 341.8 & 6.05 \\
\hline & Grodane & 6.94 & 1.78 & 380.2 & 10.08 \\
\hline & European standards ${ }^{\mathrm{b}}$ & 0.3 & 0.3 & - & - \\
\hline \multirow[t]{4}{*}{ Pea } & Douce P & 0.4282 & 1.399 & 47.99 & 5.163 \\
\hline & Feltham & 0.2615 & 0.547 & 36.82 & 5.727 \\
\hline & Pilot & 0.1785 & 0.508 & 59.9 & 6.722 \\
\hline & European standards ${ }^{\mathrm{b}}$ & 0.05 & 0.2 & - & - \\
\hline \multirow[t]{4}{*}{ Onion } & Buffalo & 4.0229 & 6.486 & 50.45 & 2.374 \\
\hline & Express & 3.5566 & 8.745 & 60.94 & 3.078 \\
\hline & Shenshyu & 3.7283 & 7.77 & 31.0 & 2.693 \\
\hline & European standards ${ }^{b}$ & 0.2 & 0.3 & - & - \\
\hline \multirow[t]{4}{*}{ Lettuce } & Corsair & 9.033 & 11.73 & 160.69 & 12.55 \\
\hline & Little Gem & 8.173 & 19.68 & 172.17 & 9.97 \\
\hline & Paris island & 7.948 & 9.97 & 142.57 & 6.73 \\
\hline & European standards ${ }^{\mathrm{b}}$ & 0.3 & 0.3 & - & - \\
\hline
\end{tabular}

\footnotetext{
${ }^{\mathrm{b}}$ Maximum levels for certain contaminants in foodstuffs on the basis of Commission Regulation (EC) No 1881/2006 of 19 December 2006 and amending Regulation No 420/2011 of 29 April 2011
} 
Table 3 Concentrations of heavy metals in edible parts of vegetables from Germany, depending on species ( $\mathrm{mg} / \mathrm{kg})$. Data show mean \pm standard error of three replicates Säumel et al. (2012)

\begin{tabular}{|c|c|c|c|c|c|c|c|}
\hline Vegetable type & Vegetable species & $\mathrm{Pb}(\mathrm{mg} / \mathrm{kg})$ & $\mathrm{Cd}(\mathrm{mg} / \mathrm{kg})$ & $\mathrm{Cr}(\mathrm{mg} / \mathrm{kg})$ & $\mathrm{Ni}(\mathrm{mg} / \mathrm{kg})$ & $\mathrm{Cu}(\mathrm{mg} / \mathrm{kg})$ & $\mathrm{Zn}(\mathrm{mg} / \mathrm{kg})$ \\
\hline \multirow[t]{2}{*}{ Stem } & Kohlrabi & $0.1-3.1$ & $0.03-0.15$ & $0.07-0.54$ & $0.29-0.67$ & $3.2-11.7$ & $20.6-50.3$ \\
\hline & European standards ${ }^{\mathrm{b}}$ & 0.3 & 0.1 & - & - & - & - \\
\hline \multirow[t]{3}{*}{ Root } & Carrot & $1.3-28.5$ & $0.06-0.41$ & $0.1-2.39$ & $0.07-1.93$ & $5.4-23.2$ & $23.3-122.8$ \\
\hline & Potato & $0.3-31.3$ & $0.02-0.42$ & $0.03-4.69$ & $0.03-3.25$ & $3.4-20.1$ & $11.7-78.2$ \\
\hline & European standards ${ }^{\mathrm{b}}$ & 0.1 & 0.1 & - & - & - & - \\
\hline \multirow[t]{2}{*}{ Solanaceous } & Tomato & $0.1-6.7$ & $0.01-0.79$ & $0.11-0.63$ & $0.03-0.70$ & $3.5-16.0$ & $15.8-84.7$ \\
\hline & European standards ${ }^{\mathrm{b}}$ & 0.1 & 0.05 & - & - & - & - \\
\hline \multirow[t]{2}{*}{ Legume } & Green beans & $0.1-3.5$ & $0.01-0.04$ & $0.08-0.46$ & $0.27-1.3$ & $3.5-10.5$ & $32.4-44.2$ \\
\hline & European standards ${ }^{\mathrm{b}}$ & 0.2 & 0.05 & - & - & - & - \\
\hline \multirow[t]{2}{*}{ Leafy } & White Cabbage & $0.6-2.6$ & $0.06-0.41$ & $0.025-0.81$ & $0.01-1.0$ & $3.2-6.6$ & $26.4-46.5$ \\
\hline & European standards ${ }^{\mathrm{b}}$ & 0.3 & 0.2 & - & - & - & - \\
\hline
\end{tabular}

${ }^{\mathrm{b}}$ Maximum levels for certain contaminants in foodstuffs on the basis of Commission Regulation (EC) No 1881/2006 of 19 December 2006 and amending Regulation No 420/2011 of 29 April 2011

However, she found that, in the studied plants, concentrations of nickel, chromium, and cadmium were the highest in roots, while lead levels were the highest in leaves. Only in the case of cadmium acidic soil significantly contributed to an increase in its content in the studied plants. For the remaining studied metals, this effect was small.

Zhou et al. (2016) reported that there are clear differences in heavy metal concentrations in edible parts of various vegetables. The ability to uptake and accumulate heavy metals was the highest in leafy vegetables and the lowest in melon vegetables (Table 1).

Alexander et al. (2006) reported that $\mathrm{Cd}, \mathrm{Cu}$, and $\mathrm{Zn}$ accumulated to the largest extent in lettuce and spinach, while the highest accumulation of $\mathrm{Pb}$ was noted in lettuce and onions. They also demonstrated that vegetables of the same species accumulated different amounts of heavy metals depending on a cultivar (Table 2).

Yang et al. (2009) found that cucumber, radish, and tomato had lower concentrations of $\mathrm{Cd}$ in their edible parts than pak choi, Chinese leek, and carrots. Accumulation of $\mathrm{Cd}$ by different plant species increases in the following order: legumes vegetables $<$ melon vegetables $<$ alliums vegetables $<$ root vegetables $<$ solanaceous vegetables $<$ leafy vegetables.

Säumel et al. (2012) reported that the concentration of heavy metals in leafy vegetables is higher than in potato, carrot, tomato, kohlrabi, and green bean seeds (Table 3).
Zhong et al. (2017) reached similar conclusions on the basis of tests conducted on three types of vegetables. They have found that the concentration of heavy metals in edible parts was the highest in leaf vegetables, lower in root vegetables, and the lowest in fruit vegetables.

Kabata-Pendias and Pendias (1999), Kabata-Pendias (2000) included root vegetables in plants particularly susceptible to cadmium accumulation. Furthermore, they reported that cadmium is uptaken extremely easily, both by the root system and leaves, generally in proportion to its concentration in the environment, regardless of the soil properties. However, acidic soil is considered to be the most important factor influencing its increased phyto-assimilation. Cadmium is characterized by a high (up to 10) bioaccumulation index, and its content in plants is frequently directly proportional to its content in the ground.

\section{Conclusions}

- Cultivation of vegetables in regions characterized by high density of industrial factories, or near busy roads results in significant contamination of crops with heavy metals.

- Irrigation of agricultural fields with wastewater leads to their significant contamination with heavy metals and, thereby, to accumulation of metals in vegetables cultivated there. 
- It is necessary to maintain a reasonable approach to fertilizing and the use of plant protection products, because they also increase accumulation of these metals in plants.

- Leafy vegetables and root vegetables have the greatest ability to accumulate heavy metals; therefore, they are not suitable for growing on contaminated soils.

Open Access This article is distributed under the terms of the Creative Commons Attribution 4.0 International License (http:// creativecommons.org/licenses/by/4.0/), which permits unrestricted use, distribution, and reproduction in any medium, provided you give appropriate credit to the original author(s) and the source, provide a link to the Creative Commons license, and indicate if changes were made.

\section{References}

Akbar, F., Ishaq, M., Ihsanullah, I., \& Asim, S. M. (2009). Multivariate statistical analysis of heavy metals pollution in industrial area and its comparison with relatively less polluted area: a case study from the City of Peshawar and District Dir Lower. Journal of Hazardous Materials, 176, 609-616. https://doi.org/10.1016/j.jhazmat.2009.11.073.

Alexander, P. D., Alloway, B. J., \& Dourado, A. M. (2006). Genotypic variations in the accumulation of $\mathrm{Cd}, \mathrm{Cu}, \mathrm{Pb}$ and $\mathrm{Zn}$ exhibited by six commonly grown vegetables. Environmental Pollution, 144, 736-745. https://doi. org/10.1016/j.envpol.2006.03.001.

Antisari, L. V., Orsini, F., Marchetti, L., Vianello, G., \& Gianquinto, G. (2015). Heavy metal accumulation in vegetables grown in urban gardens. Agronomy for Sustainable Development, 35, 1139-1147. https://doi.org/10.1007 /s13593-015-0308-z.

Attanayake, C. P., Hettiarachchi, G. M., Harms, A., Presley, D., Martin, S., \& Pierzynski, G. M. (2014). Field evaluations on soil plant transfer of lead from an urban garden soil. Journal of Environmental Quality, 43, 475. https://doi.org/10.2134 /jeq2013.07.0273.

Attanayake, C. P., Hettiarachchi, G. M., Martin, S., \& Pierzynski, G. M. (2015). Potential bioavailability of lead, arsenic, and polycyclic aromatic hydrocarbons in compost-amended urban soils. Journal of Environmental Quality, 44, 930-944. https://doi.org/10.2134/jeq2014.09.0400.

Bai, J., Xiao, R., Cui, B., Zhang, K., Wang, Q., Liu, X., Gao, H., \& Huang, L. (2011). Assessment of heavy metal pollution in wetland soils from the young and old reclaimed regions in the Pearl River Estuary, South China. Environmental Pollution, 159, 817-824. https://doi.org/10.1016/j.envpol.2010.11.004.

Bielecka, A., Ryłko, E., \& Bojanowska, I. (2009). Zawartość pierwiastków metalicznych w glebach i warzywach $\mathrm{z}$ ogrodów działkowych Gdańska i okolic (Contents of metals in soils and vegetables from Gdansk and Straszyn allotments). Environmental Protection and Natural Resources., 40, 209-216 In polish.

Brown, S. L., Clausen, I., Chappell, M. A., Scheckel, K. G., Newville, M., \& Hettiarachchi, G. M. (2012). High-iron biosolids compost-induced changes in lead and arsenic speciation and bioaccessibility in co-contaminated soils. Journal of Environmental Quality, 41, 1612. https://doi.org/10.2134 /jeq2011.0297.

Czarnowska, K., \& Bednarz, I. (2000). Metale ciężkie w pyle ulicznym Warszawy (Heavy metals in street dust from Warsaw). Roczniki Gleboznawcze - Soil Science Annual, 51, 29-36.

Defoe, P. P., Hettiarachchi, G. M., Benedict, C., \& Martin, S. (2014). Safety of gardening on lead- and arseniccontaminated urban brownfields. Journal of Environmental Quality, 43, 2064-2078. https://doi.org/10.2134 /jeq2014.03.0099.

Filipiak-Szok, A., Kurzawa, M., \& Szlyk, E. (2015). Determination of toxic metals by ICP-MS in Asiatic and European medicinal plants and dietary supplements. Journal of Trace Elements in Medicine and Biology, 30, 54-58. https://doi.org/10.1016/j.jtemb.2014.10.008.

Finžgar, N., Kos, B., \& Leštan, D. (2006). Bioavailability and mobility of $\mathrm{Pb}$ after soil treatment with different remediation methods. Plant, Soil and Environment, 52, 25-34. https://doi. org/10.17221/3342-PSE.

Hu, B., Jia, X., Hu, J., Xu, D., Xia, F., \& Li, Y. (2017). Assessment of heavy metal pollution and health risks in the soil-planthuman system in the Yangtze River Delta, China. International Journal of Environmental Research and Public Health, 14, 1042. https://doi.org/10.3390 /ijerph14091042.

Intawongse, M., \& Dean, J. R. (2006). Uptake of heavy metals by vegetable plants grown on contaminated soil and their bioavailability in the human gastrointestinal tract. Food Additives and Contaminants, 23, 36-48. https://doi. org/10.1080/02652030500387554.

Jan, F. A., Ishaq, M., Khan, S., Ihsanullah, I., Ahmad, I., \& Shakirullah, M. (2010). A comparative study of human health risks via consumption of food crops grown on wastewater irrigated soil (Peshawar) and relatively clean water irrigated soil (lower Dir). Journal of Hazardous Materials, 179, 612-621. https://doi.org/10.1016/j. jhazmat.2010.03.047.

Järup, L. (2003). Hazards of heavy metal contamination. British Medical Bulletin, 68, 167-182. https://doi.org/10.1093 /bmb/ldg032.

Kabata-Pendias, A. (2000). Biogeochemia kadmu. Kadm w środowisku - problemy ekologiczne i metodyczne. Zeszyty Naukowe Komitetu Cztowiek i środowisko PAN, 26, 17-24 In polish.

Kabata-Pendias, A., \& Pendias, H. (1999). Biogeochemia pierwiastków śladowych. Warsaw: PWN In polish.

Karami, N., Clemente, R., Moreno-Jiménez, E., Lepp, N. W., \& Beesley, L. (2011). Efficiency of green waste compost and biochar soil amendments for reducing lead and copper mobility and uptake to ryegrass. Journal of Hazardous Materials, 191, 41-48. https://doi.org/10.1016/j. jhazmat.2011.04.025.

Karczewska, A., Lewińska, K., Agata, M., \& Krysiak, A. (2010). Soil pollution by arsenic within the allotment gardens in 
Zloty Stok. Ecological Chemistry and Engineering A, 17, 927-933.

Khan, S., Cao, Q., Zheng, Y. M., Huang, Y. Z., \& Zhu, Y. G. (2008). Health risks of heavy metals in contaminated soils and food crops irrigated with wastewater in Beijing, China. Environmental Pollution, 152, 686-692. https://doi. org/10.1016/j.envpol.2007.06.056.

Khan, K., Khan, Y., Lu, H., Ishtiaq, M., Khan, S., Waqas, M., Wei, L., \& Wang, T. (2013). Heavy metals in agricultural soils and crops and their health risks in Swat District, northern Pakistan. Food and Chemical Toxicology, 58, 449-458. https://doi.org/10.1016/j.fct.2013.05.014.

Kishan, P. S., Bhattacharya, S., \& Sharma, P. (2014). AmericanEurasian assessment of heavy metal contents of some Indian medicinal plants. Journal of Agricultural \& Environmental Sciences, 14, 1125-1129. https://doi.org/10.5829/idosi. aejaes.2014.14.10.12447.

Kumar, N., Kumar, S., Bauddh, K., Dwivedi, N., Shukla, P., Singh, D. P., \& Barman, S. C. (2015). Toxicity assessment and accumulation of metals in radish irrigated with battery manufacturing industry effluent. International Journal of Vegetable Science, 00, 1-13. https://doi.org/10.1080 /19315260.2014.880771.

Leitzmann, C. (2003). Nutrition ecology: the contribution of vegetarian diets. The American Journal of Clinical Nutrition, 78, 657S-659S. https://doi.org/10.1093/ajcn/78.3.657S.

Lim, M. P., \& McBride, M. B. (2015). Arsenic and lead uptake by Brassicas grown on an old orchard site. Journal of Hazardous Materials, 299, 656-663. https://doi. org/10.1016/j.jhazmat.2015.07.082.

Lityński, T., \& Jurkiewicz, H. (1982). Żyzność gleby i odżywianie się roślin. Warszawa: PWN In polish.

Lough, G., Schauer, J. J., Park, J. S., Shafer, M. M., Deminter, J. T., \& Weinstein, J. (2005). Emissions of metals associated with motor vehicle roadways. Environmental Science \& Technology, 39, 826-836. https://doi.org/10.1021/es048715f.

Mahmood, A., \& Malik, R. N. (2014). Human health risk assessment of heavy metals via consumption of contaminated vegetables collected from different irrigation sources in Lahore, Pakistan. Arabian Journal of Chemistry, 7, 91-99. https://doi.org/10.1016/j.arabjc.2013.07.002.

McBride, M.B., Shayler, H.A., Spliethoff, H.M., Mitchell, R.G., Marquez-Bravo, L.G., Ferenz, G.S., Russell-Anelli, J.M., Casey, L., Bachman, S. (2014). Concentrations of lead, cadmium and barium in urban garden-grown vegetables: the impact of soil variables. Environmental Pollution, 194, 254-261. https://doi.org/10.1016/j.envpol.2014.07.036.

McBride, M. B., Shayler, H. A., Russell-Anelli, J. M., Spliethoff, H. M., \& Marquez-Bravo, L. G. (2015). Arsenic and lead uptake by vegetable crops grown on an old orchard site amended with compost. Water, Air, \& Soil Pollution, 226, 265-279. https://doi.org/10.1007/s11270-015-2529-9.

Murray, H., Pinchin, T. A., \& Macfie, S. M. (2011). Compost application affects metal uptake in plants grown in urban garden soils and potential human health risk. Journal of Soils and Sediments, 11, 815-829. https://doi.org/10.1007 /s11368-011-0359-y.

Nieć, J., Baranowska, R., Dziubanek, G., \& Rogala, D. (2013). Narażenie środowiskowe dzieci na metale ciężkie zawarte w glebach z placów zabaw, boisk, piaskownic i terenów przedszkoli z obszaru Górnego Śląska. Journal of Ecology and Health, 2, 55-62 In polish.

Paltseva, A., Cheng, Z., Deeb, M., Groffman, P. M., Shaw, R. K., \& Maddaloni, M. (2018). Accumulation of arsenic and lead in garden-grown vegetables: factors and mitigation strategies. The Science of the Total Environment, 640-641, 273-283. https://doi.org/10.1016/j.scitotenv.2018.05.296.

Pueyo, M., Lopez-Sanchez, J. F., \& Rauret, G. (2004). Assessment of $\mathrm{CaCl} 2, \mathrm{NaNO} 3$, and $\mathrm{NH} 4 \mathrm{NO} 3$ extraction procedures for the study of $\mathrm{Cd}, \mathrm{Cu}, \mathrm{Pb}$ and $\mathrm{Zn}$ extractability in contaminated soils. Analytica Chimica Acta, 504, 217-225.

Rodriguesa, A. A. Z., De Queiroz, M. E. L. R., Oliveira, A. F., Heleno, A. A. F. F., Zambolim, L., Freitasa, J. F., \& Morais, E. H. C. (2017). Pesticide residue removal in classic domestic processing of tomato and its effects on product quality. Journal of Environmental Science and Health. Part. B, 52, 1-8. https://doi.org/10.1080/03601234.2017.1359049.

Säumel, I., Kotsyuk, I., Hölscher, M., Lenkereit, C., Weber, F., \& Kowarik, I. (2012). How healthy is urban horticulture in high traffic areas? Trace metal concentrations in vegetable crops from plantings within inner city neighbourhoods in Berlin, Germany. Environmental Pollution, 165, 124-132. https://doi.org/10.1016/j.envpol.2012.02.019.

Scheckel, K. G., Diamond, G. L., Burgess, M. F., Klotzbach, J. M., Maddaloni, M., Miller, B. W., Partridge, C. R., \& Serda, S. M. (2013). Amending soils with phosphate as means to mitigate soil lead hazard: a critical review of the state of the science. Journal of Toxicology and Environmental Health, Part B: Critical Reviews, 16, 337-380. https://doi. org/10.1080/10937404.2013.825216.

Shaheen, N., Irfan, N. M., Khan, I. N., Islam, S., Islam, M. S., \& Ahmed, M. K. (2016). Presence of heavy metals in fruits and vegetables: health risk implications in Bangladesh. Chemosphere, 152, 431-438. https://doi.org/10.1016/j. chemosphere.2016.02.060.

Śmiechowska, M., \& Florek, A. (2011). Content of heavy metals in selected vegetablesfrom conventional, organic and allotment cultivation. Journal of Research and Applications in Agricultural Engineering, 56, 152-156.

Sternbeck, J., Sjödin, A., \& Andréasson, K. (2002). Metal emissions from road traffic and the influence of resuspensionresults from two tunnel studies. Atmospheric Environment, 36, 4735-4744. https://doi.org/10.1016/S1352-2310(02 00561-7.

Sun, Z., \& Chen, J. (2018). Risk assessment of potentially toxic elements (PTEs) pollution at a rural industrial wasteland in an abandoned metallurgy factory in North China. International Journal of Environmental Research and Public Health, 15, 85. https://doi.org/10.3390/ijerph15010085.

Sung, C. Y., \& Park, C. B. (2018). The effect of site- and landscape-scale factors on lead contamination of leafy vegetables grown in urban gardens. Landscape and Urban Planning, 177, 38-46. https://doi.org/10.1016/j. landurbplan.2018.04.013.

Szatanik-Kloc, A. (2004). Wpływ pH i stężenie wybranych metali ciężkich w glebie na ich zawartość w roślinach. Acta Agrophysica, 4, 177-183 In polish.

Wang, Q., Cui, Y., Liu, X., Dong, Y., \& Christie, P. (2003). Soil contamination and plant uptake of heavy metals at polluted sites in China. Journal of Environmental Science and Health, 
Part A, 38, 823-838. https://doi.org/10.1081/ESE120018594.

WHO. 2004. Fruit and Vegetables for Health -Report of a Joint FAO/WHO Workshop, 1-3 September 2004, http://www. fao.org/3/a-y5861e.pdf, Accesed January 2019.

WIOŚ Szczecin. 2015. Stan środowiska w województwie zachodniopomorskim Wojewódzki Inspektorat Ochrony Środowiska w Szczecinie. Report 2015. Accesed January 2019. www.wios.szczecin.pl/bip/files/.../VII_Ochrona_ powietrza.pdf. In polish.

Wiseman, C. L., Zereini, S. F., \& Püttmann, W. (2013). Trafficrelated trace element fate and uptake by plants cultivated in roadside soils in Toronto, Canada. The Science of the Total Environment, 442, 86-95. https://doi.org/10.1016/j. scitotenv.2012.10.051.

Wiseman, C. L., Zereini, S. F., \& Püttmann, W. (2015). Metal and metalloid accumulation in cultivated urban soils: a mediumterm study of trends in Toronto, Canada. The Science of the Total Environment, 15, 564-572. https://doi.org/10.1016/j. scitotenv.2015.08.085.

Właśniewski, S., \& Hajduk, E. (2012). Akumulacja kadmu w glebach i wybranych warzywach uprawianych w ogrodach działkowych Rzeszowa. Roczniki Gleboznawcze - Soil Science Annual, 48, 55-60. In polish.

Wojciechowska-Mazurek, M., Starska, K., Brulińska-Ostrowska, E., Plewa, M., Biernat, U., \& Karłowski, K. (2008). Monitoring of contamination of foodstuffs with elements noxious to human health. Part I. Wheat cereal products, vegetable products, confectionery and products for infants and children (2004 year). Rocznik PZH, 59, 251-266.

Wong, C. S. C., Li, X., \& Thornton, I. (2006). Urban environmental geochemistry of trace metals. Environmental Pollution, 142, 1-16. https://doi.org/10.1016/j.envpol.2005.09.004.

Wuana, R. A., \& Okieimen, F. E. (2011). Heavy metals in contaminated soils: a review of sources, chemistry, risks and best available strategies for remediation. ISRN Ecology, 1-20. https://doi.org/10.5402/2011/402647.

Yang, Y., Zhang, F. S., Li, H. F., \& Jiang, R. F. (2009). Accumulation of cadmium in the edible parts of six vegetable species grown in Cd-contaminated soils. Journal of Environmental Management, 90, 1117-1122. https://doi. org/10.1016/j.jenvman.2008.05.004.

Yang-Guang, G., Qin, L., \& Yan-Peng, G. (2016). Metals in exposed-lawn soils from 18 urban parks and its human health implications in southern China's largest city, Guangzhou. Journal of Cleaner Production, 115, 122-129. https://doi. org/10.1016/j.jclepro.2015.12.031.

Ye, X., Xiao, W., Zhang, Y., Zhao, S., Wang, G., Zhang, Q., \& Wang, Q. (2015). Assessment of heavy metal pollution in vegetables and relationships with soil heavy metal distribution in Zhejiang province, China. Environmental Monitoring and Assessment, 187, 378. https://doi.org/10.1007/s10661015-4604-5.

Zereini, F., Wiseman, C. L. S., \& Püttmann, W. (2007). Changes in palladium, platinum, and rhodium concentrations, and their spatial distribution in soils along a major highway in Germany from 1994 to 2004. Environmental Science \& Technology, 41, 451-456. https://doi.org/10.1021/es061453s.

Zereini, F., Alsenz, H., Wiseman, C. L. S., Püttmann, W., Reimer, E., Schleyer, R., Bieber, E., \& Wallasch, M. (2012). Platinum group elements $(\mathrm{Pt}, \mathrm{Pd}, \mathrm{Rh})$ in airborne particulate matter in rural vs. urban areas of Germany: concentrations and spatial patterns of distribution. The Science of the Total Environment, 416, 261-268. https://doi.org/10.1016/j. scitotenv.2011.11.070.

Zhang, M. K., Liu, Z. Y., \& Wang, H. (2010). Use of single extraction methods to predict bioavailability of heavy metals in polluted soils to rice. Communications in Soil Science and Plant Analysis, 41, 820-831. https://doi.org/10.1080 /00103621003592341.

Zhong, T., Xue, D., Zhao, L., \& Zhang, X. (2017). Concentration of heavy metals in vegetables and potential health risk assessment in China. Environmental Geochemistry and Health, 40, 313-322. https://doi.org/10.1007/s10653-017-9909-6.

Zhou, H., Yang, W. T., Zhou, X., Liu, L., Gu, J. F., Wang, W. L., Zou, J. L., Tian, T., Peng, P. Q., \& Liao, B. H. (2016). Accumulation of heavy metals in vegetable species planted in contaminated soils and the health risk assessment. International Journal of Environmental Research and Public Health, 13, 289. https://doi.org/10.3390 /ijerph13030289.

Publisher's Note Springer Nature remains neutral with regard to jurisdictional claims in published maps and institutional affiliations. 